\title{
Information Support of Russian Media for the Tourist Destination of Crimea
}

\author{
Aleksander Panasiuk *(D) and Halyna Zubrytska (D) \\ Institute of Entrepreneurship, Tourism and Sport Management Chair, Jagiellonian University, \\ 30-348 Kraków, Poland; halyna.zubrytska@uj.edu.pl \\ * Correspondence: aleksander.panasiuk@uj.edu.pl; Tel.: +48-126-645-720
}

check for

updates

Citation: Panasiuk, A.; Zubrytska, H Information Support of Russian Media for the Tourist Destination of Crimea. Sustainability 2021, 13, 3228. https://doi.org/10.3390/su13063228

Academic Editor: Marek Nowacki

Received: 19 February 2021

Accepted: 11 March 2021

Published: 15 March 2021

Publisher's Note: MDPI stays neutral with regard to jurisdictional claims in published maps and institutional affiliations.

Copyright: (c) 2021 by the authors. Licensee MDPI, Basel, Switzerland. This article is an open access article distributed under the terms and conditions of the Creative Commons Attribution (CC BY) license (https:// creativecommons.org/licenses/by/ $4.0 /)$.

\begin{abstract}
Crimea is a very attractive tourist destination with a high rank of tourist values, being natural and cultural heritage, with high recognition on the international tourist market. Since 2014, the tourism economy has been in a protracted crisis, caused by both internal and external reasons. The annexation of Crimea by the Russian Federation in March 2014 significantly exacerbated the problems of the functioning of the tourism economy, preventing its sustainable development. The Russian authorities are taking political as well as socioeconomic measures to rebuild the tourism economy of Crimea, by taking steps to increase tourist traffic in Crimea, especially within the country, i.e., from other regions of Russia. One of the directions of actions to overcome the crisis is information support by the Russian media, the analysis of which is presented in this article. The aim of the study is therefore an attempt to evaluate the effectiveness of information support by the Russian media for the tourist destination of Crimea in 2014-2019. Media activities are part of the Russian government's tourism policy in this area. The article deals with the following theoretical issues: tourism policy, sustainable tourism development, heritage as the subject of tourism policy impact, information management, crisis management, the role of information in crisis management. The empirical part presents: the genesis and development of the crisis in the tourist destination of Crimea, the activity of the Russian authorities in terms of impact on the crisis, an analysis of the use of information by the Russian media in overcoming the crisis in the Crimean tourism economy.
\end{abstract}

Keywords: crises management; information management; tourism policy; tourist destination; information in tourism; Crimea

\section{Introduction}

\subsection{Preliminary Issues}

The collapse of the communist system at the end of the 20th century led to the emergence of new independent states on the political map of the world. Liberalization of the economies of the former participants of the Council for Mutual Economic Assistance (Comecon) significantly affected their tourism industries [1] (p. 227). At the same time, along with new economic opportunities, new problems appeared [2]. In a number of post-communist countries (such as Poland, Hungary, Czech Republic, the Baltic countries) tourism has become one of the important components of their economies, and largely reflects the existing global trends and structural changes [3]. However, the complex processes of the transition period in the tourism industry are not completely finished in most of the other post-communist countries [4]. The well-known sensitivity of tourist destinations to many external factors and crisis situations has a significant impact on these processes [5-8].

In this context, the study of the tourist destination of Crimea is of particular interest, which is determined by several factors. On the one hand, before the events of 2014 "the peninsula was actually considered a hidden gem of a tourist spot" [9] and was even included by the magazine National Geographic in the list "Best Trips 2013" [10]. On the other hand, the occupation of the peninsula by Russia in 2014 had a strong impact 
not only on the entire tourism industry of Crimea, but also significantly changed the quality of life for most of the population on the peninsula [11] (p. 1706). As a result, the tourism industry, which is usually not a strategic sector of the economy that requires special protection or support from the state [12], has become one of the important elements of the socioeconomic policy of modern Russia. This is confirmed by a large number of publications about tourism in Crimea in the Russian media in 2014-2019 [13] (p. 37), who informed Russian citizens about the government's successes in the development of tourism infrastructure, and, as a result, the constant growth of tourist flows. However, the objectivity and reliability of these news reports were constantly questioned and criticized by some researchers [14] (p. 304), [15] (p. 15). Based on this, the aim of the article is to assess the success of information support from the Russian media for the tourist destination of Crimea in 2014-2019, taking into account its real state. Based on this, the aim of the article is to assess the effectiveness of information support by Russian media for the tourist destination of Crimea in 2014-2019. Media activities are part of the tourism policy of the Russian authorities in this area and result from the deepening crisis in the tourism economy, obtained from the limited interest in inbound tourism to Crimea, primarily foreign, but also from other regions of the Russian Federation. The article has theoretical and analytical framework. Methods of critical analysis of the literature on the subject and source material, logical operations, methods of quantitative research to present the state of functioning of the tourism economy in Crimea and issues related to media support, as well as qualitative research to present the activities of Russian public entities in order to support Crimea as a tourist destination were used.

The following research questions were defined: (1) how and with what force does the political crisis affect the functioning of the tourism economy in Crimea? (2) how is the media participating in the information management system to mitigate the effects of the Crimean tourism destination crisis? (3) which sociopolitical events constitute the content of the media's information message in order to improve the functioning of the tourism economy in Crimea? (4) what are the determinants of improving the crisis situation in Crimea's tourism economy?

In the course of the research, the following research steps were carried out regarding the role of the media in the management of a tourist destination in crisis conditions: (1) formulation of a research problem, (2) development of theoretical and empirical research concepts, (3) analysis of theoretical literature sources, (4) synthetic analysis of the main elements of the tourist attractiveness of Crimea as a tourist destination, with a rich natural and cultural heritage, (5) recognition of the reasons of the crisis in the tourist destination of Crimea, (6) analysis of source materials concerning the functioning of the tourism economy of Crimea, government documents and actions taken by public entities of the Russian Federation in relation to Crimea as a tourist destination, (7) an analysis of the activity of the Russian media in terms of activating inbound tourism to Crimea, especially via electronic media, (8) an attempt to evaluate the tourism policy implemented by the Russian authorities towards Crimea on the basis of the presented analysis of information management in the conditions of the crisis of the tourist destination of Crimea, (9) formulation of conclusions regarding the determinants of restoring Crimea to the status of a supra-regional, national and international tourist destination with a positive image among potential tourists and high inbound tourist traffic managed in accordance with the principles of sustainable development.

The main sources of data used for the purposes of the analyses were official statistics of the Russian Federation, statistical publications, reports on monitoring, and analysis of social media.

\subsection{Introduction to Tourism Policy}

The functioning of the modern economy is based on the economic order, resulting from the adaptation of institutions, mechanisms and behaviors of economic entities to changing economic factors and external circumstances to the existing economic system. This order 
is a consequence of the regulatory actions of the state, consisting in preventing negative phenomena on the market [16]. Regulation should be treated as a form of economic activity control by means of specific instruments [17]. The set of actions undertaken by public authorities in order to influence the economic order and the goals related to it is defined as a socioeconomic policy that can be conducted comprehensively or sectorally (with regard to individual sectors of the economy). One of the sectoral policies is tourism policy, which enables the state to directly influence the tourism economy [18], but also manifests itself in other profiled sectoral policies, including international and regional ones. Tourism policy should be treated as a process of tourism economy management, which is a state activity, which consists in defining economic and social goals regarding tourism, through the selection of appropriate instruments necessary for their implementation, leading to an impact on the functioning of the tourism market [6]. The state's activities in the field of tourism policy primarily are related to constant issues connected with the implementation of economic and social goals, such as protection of consumer rights, protection of the competitive market, fiscalism, labor market, price shaping, supporting tourism consumption [19], and effect on the tourist supply. The impact of public authorities on tourism market entities may also relate to ad hoc situations mainly linked with crisis situations. In such situation, the task of tourism policy authorities is to take measures to support the market, both on the supply and demand side. Such activities can be carried out thanks to direct intervention, e.g., financial support instruments for enterprises and tourist destinations, creating and cofinancing tourist consumption or through indirect promotional and informational activities. Indirect actions may be taken by public authorities themselves, but greater effectiveness can be achieved through cooperation with the media.

\subsection{Sustainable Development of Tourism}

Nowadays, socioeconomic policy, including tourism, is determined in a wider context, taking into account sustainable development (society, economy, environment). This approach is promoted in almost all European countries, although in practice it is treated in a very different way $[20,21]$. The essence of sustainable development is to shape such development, which should enable meeting the needs of today without limiting this possibility for future generations [22].

The place of sustainable development in the activities of public institutions also directly relates to the tourism economy. These activities have a special role in areas with rich natural and cultural heritage. The concept of sustainable tourism emerged from research into the relationship between tourism, the environment and development. The basis of the concept of sustainable tourism is to achieve harmony between the needs of tourists, the natural environment and local communities. Sustainable tourism concerns the broadly understood concept of tourism development that is friendly to the natural and cultural environment in tourist destinations [23]. Responsible and ethical tourism is about organizing tourist trips in a way that ensures taking full responsibility for changes caused in the lives of other people, in their social, cultural and natural environment. It also means providing tourists with a better experience and more opportunities for tourism enterprises to develop [24].

The concept of sustainable tourism development refers primarily to the determination of an acceptable increase in the size of tourist traffic that would not cause negative changes in the environment, which is decisive for the quality of life in the future. It should be emphasized that sustainable tourism is a method of functioning, organization and management of the regional and local tourism economy [25]. This means that from the tourism destination point of view, such competences are vested in public entities of territorial authority with all cooperating institutions and economic entities that mainly support inbound traffic and deal with the creation and provision of tourism offer, including in the field of natural and cultural heritage. The behavior and activity of entities operating in a tourist destination should create harmonious relations between the broadly understood environment, including both the natural and anthropogenic system, and the development of tourism. 
On this basis, it can be concluded that sustainable tourism refers to a situation in which the negative consequences of tourism activities are not irreversible for the environment, while bringing positive effects to tourists, communities of reception areas, and entities providing tourism services.

The use of the concept of sustainable tourism in a tourist destination applies to all entities involved in the tourism development process, thanks to which it is implemented by tourists, residents, tourism enterprises, and the destination itself [26]. Exploitation of the environment along with the heritage available for the needs of tourist traffic should take into account the standards of tourist use [27]. The standards for the natural environment take the form of indicators of tourism capacity and absorptivity [28].

In the conditions of the crisis of tourist destination, which includes the limitation of inbound tourism, the raised issues, take on particular importance. On the one hand, the reduced level of tourist traffic affects the degradation of the elements of natural and cultural heritage to a lesser extent, but on the other hand, it has a very negative impact on the functioning of the tourism economy. Thus, it determines the imbalance between the elements of sustainable tourism (society, tourism economy, and environment). The negative effects of the crisis in a destination with a developed tourist function are observed both in the state of functioning of the tourism economy, but also in the society, mainly among those employed in entities dealing directly or indirectly with tourist traffic service. The long-term state of imbalance may lead to a deep degradation of the tourist destination, and then also affect the condition of the elements determining the tourist attractiveness of the area, including those related to the natural and cultural heritage. The task of public entities is to reduce the negative effects of the imbalance resulting from the crisis situation through the use of policy instruments, including informational ones.

\subsection{Heritage as a Subject of Influence of Tourism Policy}

The tourist product is the main category influencing the supply in a tourist destination. It is a structurally complex, spatial and multifaceted category. The tourism product is created by spatial units, and above all by tourism regions, metropolitan and peripheral areas, and in particular by economic entities (tourism enterprises) with the support of public entities and tourism organizations. A tourism product understood in this way consists of two groups of elements, i.e., tourism goods and devices and tourist services [29]. Significant elements of the tourist product are tourist values, defined as a set of elements of the natural environment and non-natural elements that are subject of interest to tourists [30]. Tourist values are the part of tourist resources (i.e., all existing attributes of the natural and cultural environment) which attracted tourists. A broader concept than a tourist value, but often equated with it, is a tourist attraction (e.g., an event). The most important aspect that distinguishes the tourist value in relation to the tourist attraction is the durability of the first component of the area tourist product.

From the point of view of the discussed considerations, it is primarily the values and tourist attractions (natural and anthropogenic) that make them treated as the basic elements determining the heritage of a place/area from the point of view of tourism traffic. Heritage consists of both tangible and intangible elements, as well as natural and cultural elements that are subject to protection by public entities (local, regional, national) and international institutions (e.g., UNESCO). These entities, as part of their socioeconomic policy, including tourism policy, undertake two groups of activities, i.e., in the field of:

- $\quad$ accessibility (i.e., making available) of heritage elements for the needs of tourist traffic,

- protection of heritage elements against excessive anthropopressure,

- crisis phenomena, e.g., climatic, natural, social and political disasters [31], which thus determine the lack of restrictions in creating a tourist offer, are factors that hinder access to tourist values, which constitute the natural and cultural heritage of a tourist destination. 


\subsection{Introduction to Information Management}

Information is a concept of a primary and elementary nature, most often considered in three aspects [32]:

- $\quad$ syntactic (concerns the amount of information that can potentially be contained in a given message),

- $\quad$ semantic (meaning and content of the message),

- pragmatic (the usefulness of the information, i.e., the value of the information contained in the message in terms of the goal pursued by the recipient).

There are therefore many approaches to the interpretation of the concept of "information". In terms of the market, F. Knight [33] understands information as "messages that reduce recipient uncertainty." According to his concept, uncertainty is related to the time difference between a decision and its implementation, being the opposite of uncertainty and being inversely proportional to risk. This means that information is what makes it possible to assume that an event is certain, risk is incomplete information, and the more complete it is, the lower the risk. In economic sciences, including management sciences, information is a special factor of production [34], being of key importance not only for economists, but also for politicians [35]. Information in the economy not only shows the state and direction of its development, but also reveals the mechanism of relations between its components. Information management controls the course of information processes in order to optimize them [36], it is a field of an organization's activity aimed at providing information to users with specific needs [37].

When addressing the issue of the role of information in management, attention should be paid to its dependence on the adopted management style. Information plays a different role in a directive style than in a democratic one. When making decisions, managers use different types of information, i.e., scientific, technical, economic, and social. This information is a form of communication between who manages and who is managed. Moreover, the place of information in management should be considered, which [38]:

- is a special form of interconnection and interaction of elements of an organization, as well as its relationship with the environment,

- $\quad$ supports all management levels and functions-from preparing and making decisions to evaluating the results of their implementation,

- is the direct reason for selecting the appropriate solution option that ensures achievement of the set goal.

Information management is aimed at acquiring, processing and diffusing data necessary for the current functioning of the organization through information on activities (informing) and information on cooperation (communication) [39], it also applies to longterm processes of the organization's functioning. The second are important in the activities of public entities within the framework of the conducted policy, including in the field of eliminating the effects of crisis situations.

\subsection{Crisis Management}

Management processes are determined by the occurrence of threats and various crisis situations. A crisis is a natural stage in the normal development of any system capable of evolution [40,41]. W. Coombs [42] defines a crisis as the perception of an unforeseen event that threatens the basic expectations of stakeholders and may affect the perception of the organization, as well as cause negative consequences. According to K. Fearn-Banks [43], a crisis is a serious event that can potentially have a negative impact on an organization or industry, as well as on its products or reputation. Initially, crisis management was considered as one of the aspects of public relations [44]. That is why the interpretation of the crisis emphasizes its communication and psychological aspects and related processes. M. Seymour [45] believes that communication is a central function of crisis management. The interest in communication when dealing with crises is logical and determined by the significant influence of the media on their intensity and 
duration [7] (p. 11). Taking measures under crisis management may be preventive or immediate (direct) [8] (p. 91). Preventive crisis management aims to prevent crises. The purpose of ad hoc crisis management is to take measures to overcome the already existing crisis situation.

\subsection{Information in Crisis Management}

In crisis situations, the processes of collecting, sending and processing all information necessary to make and implement the relevant decisions are carried out within one information space at a strictly defined time. The information itself does not play a dominant role in the information space. Complete and accurate information is still crucial in making effective decisions. However, in the information confrontation, tools and methods that multiply the impact of information and ensure the achievement of goals in short periods and over a large space come to the fore [46]. In crisis situations, the information space plays a special, decisive role [47]. In most cases, this is due to the fact that a crisis of confidence is an integral part of any crisis. As a result, there is an urgent need to restore this trust by creating a profitable flow of information. It is usually a key element of a protection and rehabilitation strategy in most crisis situations [48]. Thus, full consideration of the role of information in crisis management determines the need for analysis and its information and communication aspects, namely crisis communication [45].

Crisis communication is an activity aimed at creating information interactions (before, during and after a crisis) in order to maintain a positive reputation and minimize risk [48]. The main means of crisis communication are public relations. In this case, all communication processes, including information, related not only to the crisis itself, but also to the reaction to its occurrence and overcoming [49] are taken into account (Table 1).

Table 1. Types and features of the main means of communication. Source: [50].

\begin{tabular}{|c|c|c|c|c|}
\hline & Traditional Media & Internet & $\begin{array}{c}\text { Own } \\
\text { (Controlled) Media }\end{array}$ & Social Groups/Events \\
\hline Form & $\begin{array}{l}\text { Newspapers, magazines, } \\
\text { radio, television }\end{array}$ & $\begin{array}{l}\text { Official websites, internet } \\
\text { publications, forums }\end{array}$ & $\begin{array}{c}\text { Brochures, booklets, } \\
\text { newsletters }\end{array}$ & $\begin{array}{c}\text { Exhibitions, } \\
\text { conferences, seminars }\end{array}$ \\
\hline Objective & Informing & $\begin{array}{l}\text { Informing. } \\
\text { Answers to questions }\end{array}$ & $\begin{array}{l}\text { Promotion. } \\
\text { Full information }\end{array}$ & $\begin{array}{l}\text { Motivating } \\
\text { Repairing the } \\
\text { installation }\end{array}$ \\
\hline Directivity & Impersonal & Impersonal & Impersonal & Quasi-personal \\
\hline $\begin{array}{c}\text { Degree of } \\
\text { participation }\end{array}$ & Low & High & Medium & Medium \\
\hline Net cost & Very low & Low & Medium & Medium \\
\hline Difficulties & Competition & Competition & Distribution & Frequency \\
\hline
\end{tabular}

Practice shows that among all means of communication, the media most significantly influences the intensity and duration of a crisis [7] (p. 11). It results from their ability to provide information quickly, accessibility, wide range of recipients, versatility, and social orientation [51] (p. 152). In fact, in the modern world, the media has a huge impact on a person's life, largely determining culture, mindset and worldview. In most cases, a person perceives reality through its reflection in the media. However, in some countries, mainly with underdeveloped democratic systems, cases of unfair use of the media to conceal unwanted information and distortion of real events are not uncommon. In this case, the media can use a fairly wide variety of methods. The most effective and common of these is the transformation of the communicative side of information and the emotional impact, by distorting, hiding, and manipulating time and place. In addition, research results indicate that in most cases in crisis situations people form opinions and make decisions based on their feelings and interpreting ideas about the problems that caused them (Table 2). 
Table 2. Methods of transforming the communicative side of information. Source: own studies based on [51], [52] (p. 558).

\begin{tabular}{cc}
\hline Method & Characteristic \\
\hline $\begin{array}{c}\text { Distortion } \\
\text { (direct lie) }\end{array}$ & $\begin{array}{c}\text { A distortion of reality, in which false facts become part of reality. "A } \\
\text { brazen lie is better, because it excludes any possibility of dialogue". }\end{array}$ \\
\hline $\begin{array}{c}\text { Hiding } \\
\text { (selective reception) }\end{array}$ & $\begin{array}{r}\text { Hiding parts of unwanted information. } \\
\text { To distract attention from important information, can be used other, } \\
\text { more recent information, sensation. }\end{array}$ \\
\hline $\begin{array}{c}\text { Manipulating } \\
\text { time and place }\end{array}$ & $\begin{array}{r}\text { The information transfer procedure, time and place of its publication } \\
\text { have a direct impact on the evaluation and assimilation } \\
\text { of information. }\end{array}$ \\
\hline
\end{tabular}

However, effective use of information in crisis management is impossible without knowledge of the system and its features. In line with the research problem undertaken, it is necessary to take into account issues related to the management of regional and local tourism economy in crisis conditions. The tourism economy and its entities, like other components of the economy, are not immune to crisis situations. Crisis situations may be short-term or long-term. Short-term situations may occur in the preseason, during the tourist season and after the season. The full catalogue of crisis situations in the tourism economy is quite extensive [53], therefore, taking into account the scope of the analyses undertaken, we should limit ourselves to the following groups of determinants:

- military-sudden aggression, outbreak of hostilities, terrorism;

- political-destabilization of the political situation, especially in international relations;

- social-destabilization of the internal situation in the country, e.g., mass protests, strikes;

- economic, resulting from the existence of military, political and social conditions, having a direct impact on the weakening of the economy, up to a deep economic crisis.

In crisis situations in the tourism economy, the need for information is much greater as there is an immediate risk of significant losses, strict time limits and high levels of stress. It should be noted that the incurred losses concern not only the tourism economy, but also other components of the interdependent economy and the labor market.

\section{Materials and Methods}

When undertaking research on the state of functioning of the tourism economy in the period 2014-2019 selected for the analysis, it turned out that the statistical material presented by the governmental institutions of Russia, i.e., the Ministry of Health Resorts and Tourism of the Republic of Crimea (MRT) (website mtur.rk.gov.ru) ad State Statistical Service of the Republic of Crimea (SSS) (website crimea.gks.ru), are largely contradictory (Table 3), and therefore questionable and of little use for further analysis. This is also confirmed by the research of Ivanov [54] (p. 163). These data indicate the application of the information manipulation policy and confirm the crisis situation of the analyzed tourist destination.

Thus, the analysis of the data in Table 3 shows a large imbalance between the total number of tourists who visited Crimea and the number of tourists who did not use the services of accommodation facilities (from $24 \%$ in 2014 to $69 \%$ in 2018), with a constantly low value of the hotel room occupancy rate. The unreliability of the official statistics on tourism in Crimea is also confirmed by the findings in a special analytical report of the EU external service, "Disinformation Review" for 2018, which indicates, that "falsification of tourism statistics is carried out specifically by the Russian government and testifies to its desire to restore the reputation of a previously popular resort" [62]. 
Table 3. Contradictory official statistics about tourism in Crimea. Source: [55-61].

\begin{tabular}{|c|c|c|c|c|}
\hline \multirow[b]{2}{*}{ Year } & \multirow{2}{*}{$\begin{array}{c}\text { The Number } \\
\text { of Tourists According to } \\
\text { MRT Data }\end{array}$} & \multicolumn{2}{|c|}{ SSS data } & \multirow{2}{*}{$\begin{array}{c}\text { Percentage of Tourists Who Did Not } \\
\text { Use the Services } \\
\text { of Accommodation Facilities }\end{array}$} \\
\hline & & $\begin{array}{c}\text { Number } \\
\text { of Tourists } \\
\text { Accommodated }\end{array}$ & $\begin{array}{c}\text { Hotel Room } \\
\text { Occupancy Rate }\end{array}$ & \\
\hline 2014 & 647,270 & 489,456 & 0.16 & $24 \%$ \\
\hline 2015 & $4,598,000$ & 911,515 & 0.26 & $80 \%$ \\
\hline 2016 & $5,573,500$ & $1,700,414$ & 0.25 & $69 \%$ \\
\hline 2017 & $5,395,100$ & $1,591,251$ & 0.22 & $71 \%$ \\
\hline 2018 & $6,800,000$ & $2,083,441$ & 0.24 & $69 \%$ \\
\hline 2019 & $7,430,000$ & $\mathrm{n} / \mathrm{a}$ & $\mathrm{n} / \mathrm{a}$ & $\mathrm{n} / \mathrm{a}$ \\
\hline
\end{tabular}

Therefore, in the work research data of Russian Public Opinion Research Center (VCIOM) was used. VCIOM was founded in 1987 and regularly conducts various surveys in 130 cities of Russia, polling 1600 people. The sample represents the population aged 18 and over by sex, age, education, and type of settlement. The sample is multistaged, with a stage-by-stage selection of households and using quotas at the final stage of selection. The maximum sampling error with a 95\% probability does not exceed 3.5\% [63].

In the course of the study of information support of the Crimean tourism industry from the Russian media, the social media monitoring and analysis system Medialogia (Russia) was used. Since 2003, Medialogia has been providing round-the-clock data processing of 2413 newspapers, 512 magazines, 10 state TV channels, 57 radio stations, 533 news agencies, 45,577 online publications and 900 million social media accounts. More than 500,000 different media messages and about 90 million SMM messages are processed daily [64]. At the same time, the object-oriented search of the system in the media includes a linguistic analysis of messages (taking into account their positive or negative sentiment), an assessment of the main or episodic role of the message, and an assessment of the influence of the media, which is evaluated by the so called MediaIndex PR (Figure 1).

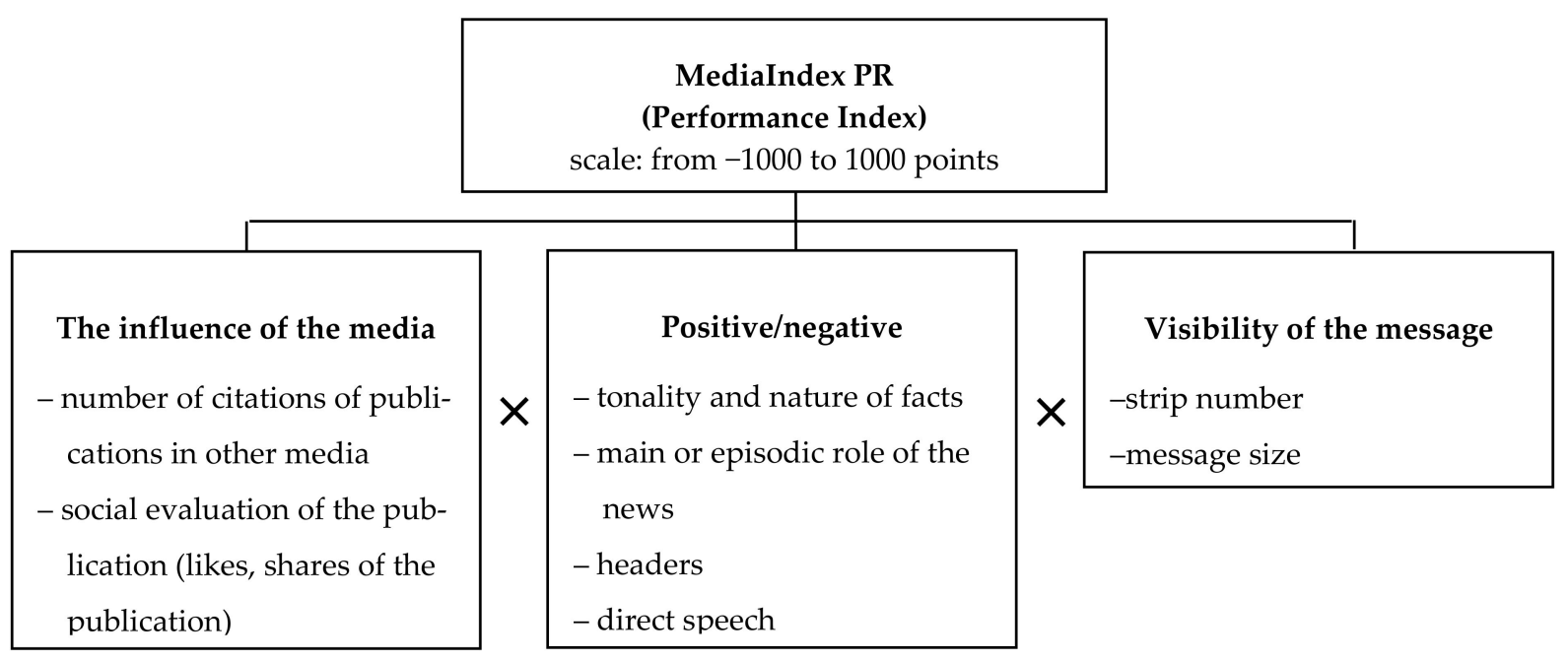

Figure 1. MediaIndex PR performance indicator Source: own study based on data provided by Medialogia.

The use of precisely Russian data from sociological studies and surveys together with the Russian system of monitoring and analysis of the media, according to the authors, should have helped in a more objective examination of the issues of the work. 


\section{Results}

\subsection{The Genesis and the Development of Crisis in the Tourist Destination of Crimea}

The tourist destination of Crimea was one of the most attractive holiday sites for the citizens of the former Soviet Union. However, in recent years, the tourism industry of the peninsula has been in a state of protracted crisis, which is caused by many, both internal and external reasons. Russia's actions in March 2014 significantly exacerbated existing problems and led to new ones. The Crimean peninsula is a unique region that has a combination of natural, climatic, historical, and cultural attractions. The possibilities for the successful development of tourism on the peninsula are determined by:

- advantageous geographical location;

- varied landscape;

- mild climate;

- natural resources of the Black and Azov seas;

- the presence of mineral waters and therapeutic mud;

- rich historical and cultural heritage.

In the Soviet Union and in the first years of Ukraine's independence, Crimea retained its sanatorium and resort specialization. Most guesthouses and sanatoriums remained the property of the ministries and large industrial enterprises of Ukraine, which used them for recreation and treatment of their employees [15]. However, the privatization of the economy, the change of ownership, as well as the economic crises of 1993 and 1998, led to the development of a shadow tourism economy [11] (p. 1706), [65]. At the same time, there was a natural aging and deterioration of the tourist infrastructure of the peninsula, which was accompanied by a lack of investment from the state and business [65], [66] (p. 90). As a result, the shadow sector took the lead, which was not controlled by the state, tax authorities or by official institutions that assess the quality of tourism services. Therefore, according to estimates in 2016, there were about 4.5 thousand private households and 14 thousand apartments on the peninsula, which provided accommodation services for more than $80 \%$ of tourists without licenses and without paying taxes [15,65], [67] (p. 13). Thus, the main specialization of Crimea as a health resort recreation on the peninsula was completely replaced by unorganized beach tourism, which was distinguished by an extremely low standard of quality of basic and additional tourist services. In fact, Crimea has become a destination for vacationers from the countries of the former Soviet Union with little financial resources and tourist needs [15].

However, the main reasons for the crisis in the tourist destination of Crimea were the events of 16 March 2014, when a referendum on the annexation of Crimea by Russia was held in violation of the Ukrainian constitution. As a result of this referendum on 17 March 2014, the "independent Republic of Crimea" was unilaterally proclaimed, and on 18 March 2014, an agreement was signed with Russia on its inclusion in it.

The events that followed led to the political and economic isolation of Crimea and became disastrous not only for the tourism industry, but for the entire economy of the peninsula:

27 March 2014 The UN General Assembly did not recognize the results of the Crimean referendum [68].

2 April 2014 European Organization for the Safety of Air Navigation banned international flights to Crimea [69] (p. 51).

7 May 2014 the water supply through the Ukrainian North-Crimean water channel was stopped, which provided more than $90 \%$ of the peninsula's water needs [70].

19 December 2014 international payment systems Visa and MasterCard stopped working in Crimea [71] (p. 465).

26 December 2014 Ukrainian railways stopped transporting goods and passengers to Crimea, transportation by road was also stopped [72] (p. 51).

31 December 2015 the supply of electricity to the peninsula from Ukraine was stopped [73].

Thus, the annexation of Crimea was not only a serious political event, but also had catastrophic economic consequences [74] (p. 57, 65). 
All this has led to a sharp decline in tourist flows since 2014. Most tourists both in Russia and in Ukraine, who previously traditionally rested in Crimea, began to prefer other domestic resorts (the territory of Odessa and Krasnodar) or choose foreign holidays in Turkey, Egypt, Bulgaria, Montenegro, and Greece [73].

High service prices in Crimea also contributed to the decrease in tourist flows. Thus, the tourism business tried to compensate its costs as much as possible [75] (p. 826), [54] (p. 164), [74] (p. 66). However, the short-term (4 months), seasonal employment of the Crimean population did not provide their average annual living wage [65] (p. 166). As a result, the cost of a budget vacation in Crimea significantly exceeded the cost of a vacation in Egypt and Turkey, with a large difference in the quality level of services and comfort.

Thus, the main features of the crisis of Crimea's tourist destination in 2014 were shadow economy, high prices, low quality of services, transport isolation, interruptions in the supply of electricity and water, a decrease in tourist flows, and a complete absence of state control of the industry.

\subsection{Actions of the Russian Government in the Context of the Crisis of the Tourist Destination of Crimea}

Taking into account the importance of the tourism industry in the peninsula's economy, the Cabinet of Ministers of Crimea in 2016 approved a "State program for the development of resorts and tourism in the Republic of Crimea for 2005-2017" [76]. The main elements of this program were the creation of elements of tourism development, which were aimed at the service of recreational, health and qualified tourism, but also in the field of cultural heritage:

- National Center for Family Rehabilitation (Evpatoria);

- mud therapy center (Saki);

- health-improving balneological complex (Chokrak lake);

- year-round tourist ski complex;

- center for extreme and archaeological tourism (Olenevka village);

- center of active types of tourism (Koktebel).

However, none of these facilities were put into operation. The analysis of government documents in Russia indicates a constant postponement of the completion dates for these facilities. Initially, they were transferred to the program "Social and economic development of the Republic of Crimea and the city of Sevastopol until 2020", the implementation of which was later also extended until 2022 [77] (p. 1). Additionally, the state program for the development of resorts and tourism in Crimea by the decision of the Cabinet of Ministers of the Crimea on 21 January 2019 does not have specific dates for its implementation at all [78].

In 2019, the newspaper Rossiyskaya Gazeta reported that more than $60 \%$ of the funds allocated to finance the tourism industry were not used [79]. At the same time, according to the official website of the Ministry of Economic Development of the Russian Federation, at the beginning of 2020, only $35 \%$ of all planned work was completed. At the same time, the work that was completed mainly concerned the reconstruction of outdated water supply and sewerage networks, the repair of roads and beaches in the resort towns of Crimea [80].

The main reasons for ignoring the problems of the tourism industry was the need for Russia to solve more vital problems that arose after the occupation of the peninsula. The main problems were the creation of a transport system connecting the peninsula with Russia, provision of Crimea with electricity and drinking water. This undoubtedly required significant efforts and financial costs on the part of Russia. As part of the solution to the transport isolation of the peninsula, Russia completed [81] (pp. 120-121):

- modernization of the Sultan Amet Khan international airport in Simferopol with the ability to receive 7 million passengers per year in 2018;

- construction of the Kerch bridge with road and rail transport in 2019;

- construction of a new four-lane highway "Tavrida" with a total length of $250 \mathrm{~km}$ in 2020 . 
- To provide Crimea with electricity [82,83]:

- in 2015, a network of expensive mobile gas turbine stations was launched;

- in 2016, the peninsula was connected by a submarine cable to the power system of southern Russia;

- in March 2019, new power units of the Balaklavskaya and Tavricheskaya thermal power systems were commissioned.

However, the most acute and still unresolved problem of the peninsula is the lack of drinking water. Currently, the main source of water in Crimea is groundwater [84]. However, the amount of water obtained from underground wells is not enough for the needs of agriculture and industry in Crimea, or for its population [85] (p. 90), [86] (p. 162), [87] (p. 58). In addition, the water in most underground sources does not meet sanitary standards and has high salinity and pollution $[88,89]$. According to Russian media reports, in October 2020, in order to provide Crimea with water until 2024, the government decided to allocate RUB 48 billion (i.e., over EUR 500 million) by redistributing funding for other Crimea programs and postponing them to a later date [90].

Of course, the implementation of these expensive, but necessary projects overshadowed the way out of the crisis in the tourism industry of the peninsula. At the same time, the Russian government implemented an information strategy that Coombs W.T. classifies as "strategy of denial" [91] (p. 247) of the existence of any crisis in tourism in Crimea. It is possible that the choice of such a strategy was influenced by the importance of Crimea in matters of Russian foreign policy. At the same time, it was important to restore the image of the tourist brand of the peninsula, which in most cases determines the attractiveness of the destination for tourists $[92,93]$.

\subsection{Using Information in Overcoming the Crisis Situation in Crimea}

As already mentioned in the theoretical part, the most common way of using media to hide or distort information is to transform the communicative side of information and shape its emotional impact on recipients.

An example of this practice is the large number of reports by the Russian media regarding Crimea before the events of 16 March 2014. Most of them contained clearly distorted information and were aimed at reducing the competitiveness of tourism in the Ukrainian Crimea. Therefore, in 2004, among the messages of the Russian news agency "New Region" one could find the following headlines: "Season of thefts in the summer in Yalta", "In Sevastopol, in broad daylight, a tourist was killed because of a video camera", "In the summer, children in Crimea are at risk of contracting listeriosis" and such [94]. At the same time, the transition to a new topic of information messages was made directly by the President of Russia on 17 April 2014: "Many recreation centers and sanatoriums (in Crimea), according to sanitary and epidemic standards, cannot be used to accommodate people. How did people rest there? (...) We must change the approach to organizing the holidays of Russians".

According to Russian experts, the media is an important instrument of influence and an element of the implementation of public administration activities in the system of social relations of modern society [95] (p. 53), [96] (pp. 26-27), [97]. This position is noted in numerous programs and legislative acts of Russia. In addition, since 2000, many of the world's specialized public relations (PR) companies (Kissinger Associates, Ketchum; GPlus Europe or EuroSCG) are working to promote the image of Russia, as well as the interests of Russian economic corporations and political leaders. The following news agencies were established for the same purposes: an international "Valdai Discussion Club", news agencies "Russia Today", "Sputnik News" and "Russia beyond the Headlines" [98] (p. 134).

However, the factor of trust is an important condition for the implementation of any information concept. Considering trust to the media as a source of information, two sides can be distinguished: who trusts and whom. For this purpose, when conducting this research, data of Russian Public Opinion Research Center (VCIOM) was used. The results of the VCIOM study on the trust of Russian citizens to the media in 2012 and 2016-2018 
are presented in Figure 2. Table 4 presents detailed data on the sources of information used by Russian citizens in terms of age and gender. Due to limited availability, the data is only for 2018.

\section{Often receive information from such media}

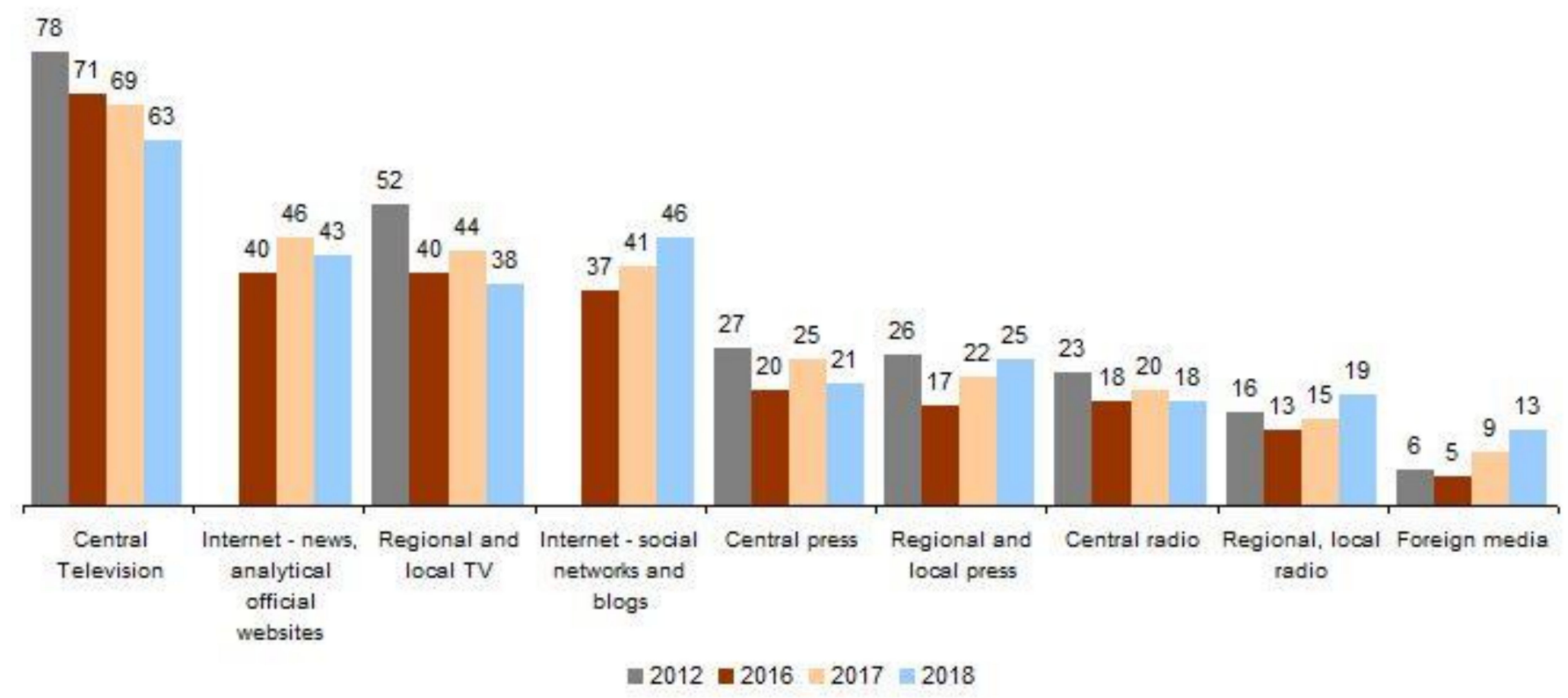

Never receive information from such media

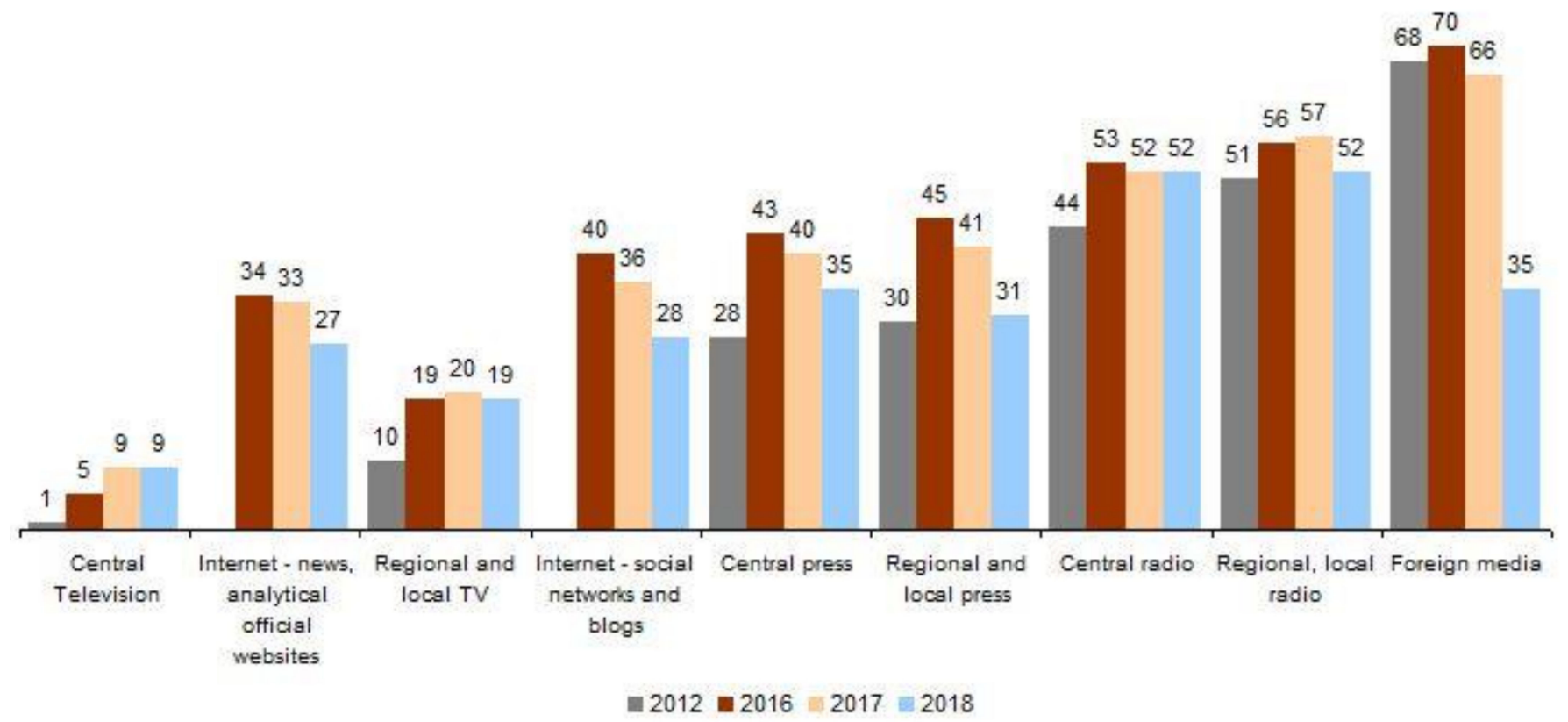

Figure 2. Information sources of Russian citizens in 2012 and 2016-2018 (in \%). Source: [99] (p. 4). 
Table 4. Information sources of Russian citizens in 2018 (in \%). Source: own studies based on [99] (p. 4).

\begin{tabular}{lccccccc}
\hline & $\mathbf{1 8 - 2 4}$ & $\mathbf{2 5 - 3 4}$ & $\mathbf{3 5 - 4 4}$ & $\mathbf{4 5 - 5 9}$ & $\mathbf{6 0 +}$ & Men & Women \\
\hline Central television & 28 & 48 & 53 & 69 & 83 & 57 & 67 \\
Regional and local TV & 21 & 29 & 26 & 41 & 54 & 32 & 42 \\
Central press & 9 & 18 & 16 & 23 & 27 & 21 & 20 \\
Regional and local press & 9 & 21 & 17 & 28 & 35 & 22 & 27 \\
Internet: official news, analytics sites & 59 & 58 & 49 & 40 & 25 & 49 & 37 \\
Internet: social networks and blogs & 79 & 64 & 51 & 43 & 23 & 47 & 46 \\
Central radio & 12 & 16 & 16 & 18 & 24 & 22 & 16 \\
Regional, local radio & 10 & 17 & 13 & 21 & 24 & 21 & 16 \\
Foreign media & 23 & 14 & 12 & 13 & 11 & 14 & 12 \\
\hline
\end{tabular}

Analysis of the data shows that the level of trust of Russian citizens towards television in 2012 and 2016-2018 was steadily declining. For central television this figure is minus $15 \%$, and for local and regional television-minus $14 \%$. Russian trust in the central and regional (local) press did not change significantly over the same period and ranged from minus $1 \%$ for the regional press to minus $6 \%$ for the central press.

At the same time, trust in news, analytical and official sites remained quite high: $43 \%$ in 2018 and $40 \%$ in 2016 (data for 2012 were not included in the study). The largest increase in trust is characteristic for social networks and blogs on the Internet: $46 \%$ in 2018 and 37\% in 2016, respectively.

The main sources of information for Russian citizens in 2018 were central television, social networks and blogs, as well as online news and analytical sites. At the same time source of information for Russians aged 18-34 is the Internet, while this age group is more focused on obtaining information from social networks and blogs. With an increase in the age category, the use of central and regional (local) television as the main source of information increases.

In the course of the study of information support of the Crimean tourism industry from the Russian media, the social media monitoring and analysis system Medialogia (Russia) was used. To obtain data in the Medialogia PR system, the following search parameters were set:

- object: "Republic of Crimea",

- context: "rest", "tourism", "travel", "resort", "treatment",

- $\quad$ media categories: newspapers, magazines, Internet, news agencies, radio, Russian television,

- $\quad$ period: 1 January 2014-31 December 2019.

The data obtained in this way (Figures 3 and 4) shows what the maximum number of information messages of the Russian media was in 2014. This is explained by the great attention to the Crimean referendum in 2014. However, we can see that since 2015 the information messages of the Russian media have changed their tonality to a more positive one, which is also reflected in the increase in annual PR-indicators of MediaIndex since 2017 (Figure 4). The largest share of positive and negative messages was reached in 2018. At the same time, the increase in the number of negative news messages in 2014-2019 is mainly associated with a wider coverage of topics:

- the consequences of EU sanctions for the tourism industry in Crimea,

- the crisis state of historical buildings, health resorts and sanatoriums of Crimea,

- high property prices. 


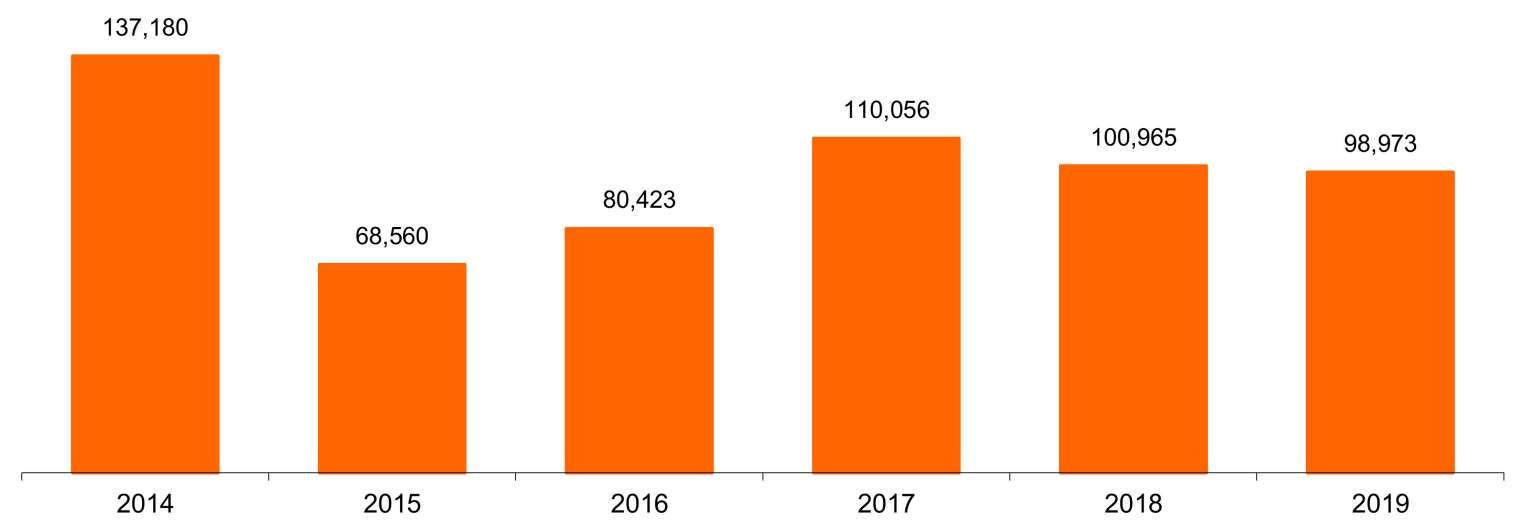

Figure 3. The number of information messages in the Russian media in the context of the tourist destination of Crimea in 2014-2019. Source: own study based on Mediologia PR data.

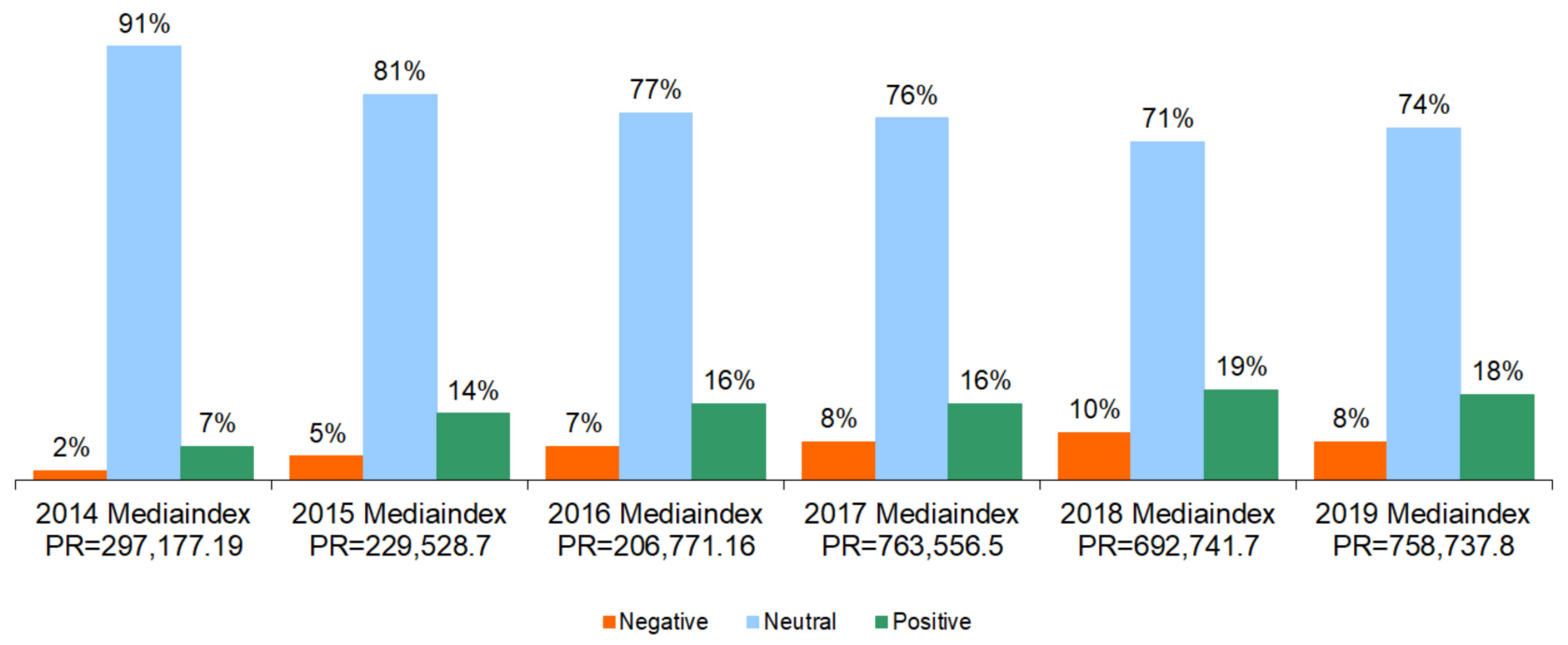

Figure 4. The impact of news releases in the Russian media in the context of the tourist destination of Crimea in 2014-2019. Source: own study based on Mediologia PR data.

The most important events that determined the most frequent information messages of the Russian media in the context of the tourist destination of Crimea and their estimated PR MediaIndex values are presented in Table 5.

In 2014, the most significant news message was "Russian Prime Minister Medvedev visits Artek and discusses the future of the children's centre". This message was used in various Russian media 574 times, had the most positive assessment (taking into account the tonality and the facts used) and visibility (page number, message volume, as well as circulation, attendance)-MediaIndex $\mathrm{PR}=1707.94$. This is due to the fact that for the majority of Russian citizens, Crimea was associated with the international children's pioneer camp Artek. The attention of the Russian government to its restoration was a kind of positive signal of the recovery of the tourism industry in Crimea. In 2015, the most significant informational message was "The new minister of tourism of Crimea has been given the difficult task of improving the quality of the activities of Crimean resorts; high expectations are ahead of him". Despite the fact that this message has been used in various Russian media 315 times and had positive assessment and visibility, MediaIndex PR was 2037.38. 
Table 5. The main events that defined the most frequent information messages of the Russian media in the context of the tourist destination of Crimea in 2014-2019. Source: own studies based on Mediologia PR data.

\begin{tabular}{|c|c|c|c|}
\hline Event of the Informational Message & $\begin{array}{l}\text { Number } \\
\text { of Posts }\end{array}$ & $\begin{array}{l}\text { Visibility } \\
\text { of the Event }\end{array}$ & $\begin{array}{l}\text { MediaIndex } \\
\text { PR }\end{array}$ \\
\hline \multicolumn{4}{|l|}{2014} \\
\hline $\begin{array}{l}\text { Russian Prime Minister Medvedev visits Artek } \\
\text { and discusses the future of the children's center }\end{array}$ & 574 & 125.02 & 1707.94 \\
\hline Single ticket for train, bus and ferry may come in summer & 253 & 62.99 & 891.63 \\
\hline The authorities want domestic flights to be cheaper than international flights & 250 & 69.57 & 231.8 \\
\hline $\begin{array}{l}\text { The State Duma of the Russian Federation believes that the gambling zone will } \\
\text { stimulate the development of Crimea }\end{array}$ & 177 & 88.08 & 2449.7 \\
\hline Crimea expects to receive 4.5 million tourists next year & 171 & 45.81 & 675.19 \\
\hline Ruslan Baysarov will deal with healing the activities of the resorts of Crimea & 163 & 47.52 & 1135.51 \\
\hline In 2014, the tourist economy of Crimea exceeded the tax collection plan 1.5 times & 167 & 32.36 & 489.28 \\
\hline Crimea and Tatarstan signed a cooperation agreement & 146 & 53.3 & 1908.72 \\
\hline Putin signed a law to create a free economic zone in Crimea & 129 & 42.68 & 616.02 \\
\hline $\begin{array}{l}\text { The Cabinet of Ministers distributes Crimean sanatoriums between the } \\
\text { departments of Russia }\end{array}$ & 117 & 34.14 & 356.61 \\
\hline \multicolumn{4}{|l|}{2015} \\
\hline $\begin{array}{l}\text { The new minister of tourism of Crimea has been given the difficult task of } \\
\text { improving the quality of the activities of Crimean resorts, high expectations are } \\
\text { ahead of him }\end{array}$ & 315 & 126.77 & 2037.38 \\
\hline $\begin{array}{l}\text { Putin will discuss the development of tourism with } \\
\text { the Presidium of the State Council in Crimea }\end{array}$ & 344 & 95.34 & 1566.43 \\
\hline $\begin{array}{l}\text { A source in the EU structures denied reports that Russian tourists visiting Crimea } \\
\text { may have their Schengen visas canceled }\end{array}$ & 321 & 89.69 & 1296.67 \\
\hline Flights to 15 new destinations will connect Crimea with Russian regions & 265 & 65.86 & 1148.95 \\
\hline Aksenov recommended to develop an alternative to trips to Egypt in the Crimea & 262 & 66.26 & 1108.82 \\
\hline $\begin{array}{l}\text { Head of the Federal Tourism Agency: } \\
\text { Russian resorts need an 'all inclusive' system }\end{array}$ & 222 & 66.56 & 1114.83 \\
\hline $\begin{array}{l}\text { The minister of resorts and tourism of Crimea } \\
\text { has denied all the allegations }\end{array}$ & 172 & 50.13 & 709.77 \\
\hline $\begin{array}{l}\text { Medvedev recommended that appropriate institutions work to improve the } \\
\text { quality of services in hotels in Crimea }\end{array}$ & 176 & 69.15 & 1020.13 \\
\hline $\begin{array}{l}\text { Crimea Minister of Tourism: the republic does not want to replace Turkey and } \\
\text { Egypt, "we are better" }\end{array}$ & 204 & 49.27 & 927.15 \\
\hline $\begin{array}{l}\text { Putin was surprised by the prohibition issued by doctors to consume wine in } \\
\text { sanatoriums: "They will go out the gates and will continue to drink!" Why forbid? }\end{array}$ & 64 & 53.1 & 1043.97 \\
\hline \multicolumn{4}{|l|}{2016} \\
\hline Tourists reviewed opinions about Crimea & 552 & 163.29 & -1194.34 \\
\hline $\begin{array}{l}\text { The influx of tourists depends on the prices offered by holiday centers, hotels and } \\
\text { sanatoriums }\end{array}$ & 405 & 111.97 & 267.21 \\
\hline The government increased the number of subsidized flights to the Crimea & 407 & 99.41 & 1634.68 \\
\hline $\begin{array}{l}\text { The number of tourists vacationing in Crimea } \\
\text { has reached the level of } 2015\end{array}$ & 197 & 34.13 & 625.1 \\
\hline $\begin{array}{l}\text { Zakharova called a paradox the statements of Western media about the failure of } \\
\text { the Crimean season }\end{array}$ & 169 & 47.27 & 579.21 \\
\hline
\end{tabular}


Table 5. Cont.

\begin{tabular}{|c|c|c|c|}
\hline Event of the Informational Message & $\begin{array}{l}\text { Number } \\
\text { of Posts }\end{array}$ & $\begin{array}{l}\text { Visibility } \\
\text { of the Event }\end{array}$ & $\begin{array}{l}\text { MediaIndex } \\
\text { PR }\end{array}$ \\
\hline Poll: most tourists are ready to come to Crimea again & 165 & 61.42 & 992.15 \\
\hline The number of tourists arriving in Crimea is increasing every week & 156 & 45.27 & 868.59 \\
\hline Crimea will attract many tourists from China & 130 & 39.29 & 705.94 \\
\hline Aksenov expects the influx of tourists to Crimea in 2016 to be huge & 121 & 33.79 & 288.43 \\
\hline Aksenov: there will be no power cuts during the season in Crimea & 62 & 36.74 & 405.88 \\
\hline \multicolumn{4}{|l|}{2017} \\
\hline The proposal to eliminate the tourist tax & 737 & 120 & 6923.4 \\
\hline $\begin{array}{l}\text { "Consistency was not enough": ministers are changed in Crimea at the peak of the } \\
\text { holiday season }\end{array}$ & 596 & 122.52 & 5732 \\
\hline $\begin{array}{l}\text { The tourist blockade of Crimea will fall } \\
\text { "on the shoulders and pockets" of Ukrainians }\end{array}$ & 430 & 83.84 & 4361 \\
\hline They want to earn RUB 16 billion on an experiment with a tourist tax in Crimea & 416 & 72.19 & 4711 \\
\hline Experts opposed the postponement of the introduction of the tourist tax in Crimea & 361 & 62.11 & 4115.1 \\
\hline Putin signs a law to implement a tourist tax & 345 & 58.4 & 3246 \\
\hline Tourist tax: where you have to pay the most & 332 & 63.23 & 4039.1 \\
\hline Aksenov: Crimea will determine the amount of tourist tax in September & 290 & 40.59 & 1835.1 \\
\hline Increase in prices for summer holidays in the current season & 263 & 23.95 & 1531 \\
\hline $\begin{array}{l}\text { The liner "Prince Vladimir" went on a cruise from Sochi to the Crimea for the first } \\
\text { time }\end{array}$ & 252 & 36.64 & 2386 \\
\hline \multicolumn{4}{|l|}{2018} \\
\hline "Let's go": Putin opened traffic on the Crimean Bridge & 335 & 110.89 & 6534 \\
\hline $\begin{array}{l}\text { "It is not the limit": Crimea has set a record for the number of tourists in the } \\
\text { post-Soviet period }\end{array}$ & 268 & 42.6 & 2765 \\
\hline There will be no tourist tax: Crimea is losing to Turkey & 256 & 51.53 & 2916 \\
\hline $\begin{array}{l}\text { The Crimean authorities asked Booking.com for clarification regarding the hotel } \\
\text { situation }\end{array}$ & 244 & 37.22 & 2671 \\
\hline Crimean resorts will reduce holiday prices & 231 & 29.64 & 1967 \\
\hline Crimea and Kuban signed an agreement on cooperation in the field of tourism & 216 & 28.18 & 2284 \\
\hline Rosturism: Crimea can break a 30-year record in the number of tourists & 157 & 34.2 & 2855 \\
\hline Daria Skippari-Smirnowa: many Finns want to see Crimea & 149 & 41.65 & 1778 \\
\hline A record number of tourists will visit Crimea by the end of the year & 127 & 16.32 & 1099 \\
\hline $\begin{array}{l}\text { Crimea has set a historical record for the number of foreigners from different } \\
\text { countries }\end{array}$ & 110 & 21.02 & 1625 \\
\hline \multicolumn{4}{|l|}{2019} \\
\hline $\begin{array}{l}\text { Simferopol-Moscow. How was the first day of selling tickets for the "Tavria" } \\
\text { trains }\end{array}$ & 374 & 111.9 & 7268 \\
\hline $\begin{array}{l}\text { Given the names of the foreign resorts where you can rest cheaper than in the } \\
\text { Crimea }\end{array}$ & 343 & 53.34 & 3541.1 \\
\hline The abolition of the tourist tax will be a good advertisement for Crimea & 195 & 46.85 & 844 \\
\hline $\begin{array}{l}\text { In Crimea, they understood why tourists preferred the resorts of southern Russia } \\
\text { to Turkey }\end{array}$ & 165 & 19.76 & 1509 \\
\hline Aksenov talks about the increase in the influx of tourists to the Crimea & 156 & 27.69 & 1411 \\
\hline
\end{tabular}


Table 5. Cont.

\begin{tabular}{|c|c|c|c|}
\hline Event of the Informational Message & $\begin{array}{l}\text { Number } \\
\text { of Posts }\end{array}$ & $\begin{array}{l}\text { Visibility } \\
\text { of the Event }\end{array}$ & $\begin{array}{l}\text { MediaIndex } \\
\text { PR }\end{array}$ \\
\hline Poklonskaya wishes courage to Kiev in resuming of the transport to the Crimea & 132 & 26.1 & 1855 \\
\hline $\begin{array}{l}\text { Since the beginning of the year, Crimea has been visited by over one hundred } \\
\text { thousand foreign tourists }\end{array}$ & 128 & 19.41 & 1390 \\
\hline Rosturism determined the minimum cost of rest in the Crimea & 124 & 24.19 & 1518 \\
\hline $\begin{array}{l}\text { "Record number for all post-Soviet years": } \\
\text { in 2018, } 6.8 \text { million people visited the Crimea }\end{array}$ & 124 & 21.4 & 1544 \\
\hline Crimean authorities invited tourists to come to the peninsula instead of Georgia & 66 & 10.01 & 436 \\
\hline
\end{tabular}

However, despite the overall positive dynamics of news reports in 2014-2015, in 2016, along with news messages of a positive tone about the rest in Crimea, there are also negative ones, for example, the message: "Tourists reviewed opinions about Crimea" (MediaIndex PR $=-1194.34$ ). However, this message is also successfully compensated by other informational messages of a positive tone. The same approach is typical for news messages 2017-2019. The analysis carried out using the Mediologia PR data system (Table 5) shows that the main informational messages of the Russian media, which concerned Crimea in 2014-2019, were aimed at providing Russians with information about the constant increase in tourist flows to Crimea, improving transport links and accessibility, the state's concern for the quality of services and interest in Crimea from foreign tourists. This was undoubtedly a serious informational support for the tourist destination of Crimea in overcoming the crisis and confirms the mercantilist approach of the Russian Federation, with government stepping in to encourage tourist flows to the area [54] (p. 166).

How effective was this information support? As was shown earlier (Table 3) official statistics of the Ministry of Resorts and Tourism of the Republic of Crimea and the State Statistical Service of the Republic of Crimea are largely contradictory and questionable. Some Russian researchers also draw attention to this circumstance. Therefore, A.N. Koshelev and I.F.-O. Mirzoev believe that the reason for the "different figures is poor knowledge of the issues" [15] (p. 15).

Unfortunately, the results of research of the Russian Public Opinion Research Center (VCIOM) show that the total number of Russians vacationing in Crimea, decreased from $9 \%$ in 2015 [100] to $4 \%$ in 2019 [101]. At the same time, according to a survey in 2019, 40\% of Russians saw no obstacles for themselves to rest in Crimea, and $24 \%$ believe that prices on vacation are high (Table 6).

Table 6. Factors limiting the interest in tourist trips to the Crimea in 2019. Source: own studies based on [100].

\begin{tabular}{cc}
\hline Criteria of Criteria of the Unattractiveness of a Tourist Trip & $\%$ \\
\hline High prices & 24 \\
Income/low salary & 9 \\
Low level of service and support & 7 \\
The distance of the location of the resting places & 5 \\
Proximity to Ukraine/terrorism & 8 \\
Safety concerns & 7 \\
Nothing disturbs the rest & 40 \\
\hline
\end{tabular}

According to the estimates of many Russian experts, the main problems of the tourism industry in Crimea remain unresolved. The main ones among them are $[75,102,103]$ :

- international isolation,

- high seasonality,

- $\quad$ noncompetitiveness (high prices, low level of services). 
The international isolation of the peninsula makes it impossible to attract foreign investment and the development of Crimea within the framework of the international tourism industry. Accordingly, at present, the main possible form of tourism development in Crimea is focusing on domestic tourism of Russian citizens and relying solely on their own resources [104] (pp. 434-435).

The problem of the seasonality of the tourism industry in Crimea determines the high level of prices during the tourist season, with the help of which market participants try to ensure the profitability of their activities. Attracting a large number of seasonal workers during this period, as a rule, without appropriate qualifications and training, in turn, determines a low level of services. As a result, most of the objects of the Crimean tourism industry are not competitive not only with Turkey and Egypt, but also with the nearest Russian resorts in the Krasnodar Territory (Sochi, Anapa, Russia).

\section{Discussion and Conclusions}

\subsection{Comments to the Research Part}

Crimea is a tourist destination with a high level of recognition on the international tourism market. The peninsula is an area of high natural and cultural heritage. Due to its location and climate, it is predisposed to the development of the tourist function. In the past decades, tourism has been an important part of the region's economy. The development of the tourism economy was interrupted by the political crisis that threatens the development of sustainable tourism in the Crimea area. The aim of this study is to assess the effectiveness of information support by Russian media for the tourist destination of Crimea in 2014-2019. On the basis of available, but not fully reliable sources, it can be stated that the information activities of the media, which are part of the tourism policy of the Russian authorities in this area, do not limit the crisis situations in the tourism economy. An indirect way to evaluate the media message addressed to potential tourists who are interested in coming to Crimea is to analyze the media messages. In the analyzed years, an increase in the positive ratings of the media influence indicator on the interest in Crimea as a tourist destination was observed from $7 \%$ in 2014 to $18 \%$ in 2018, while the negative ratings also increased and amounted to $2 \%$ and $8 \%$, respectively. The research concerns only the Russian market. There are no data on incoming foreign tourism. However, it can certainly be said that Crimea is not a destination that foreign tourists are interested in after the annexation of Crimea by Russia. On this basis, it should be stated that despite the fact that many initiatives have been carried out, the effectiveness of the media's information support and the overall tourism policy implemented by the Russian authorities in the face of the crisis in Crimea's tourism economy is low. The continued political, social and military crisis has a decisive influence on the functioning of the tourism economy in Crimea.

Despite the solutions to multiple issues on the peninsula, the tourism industry of Crimea continues to remain in a state of crisis. In the conditions of purely external causes of the crisis, the subjects of the tourism industry cannot independently solve the tasks they face and are completely dependent on the actions of the authorities. At the same time, the information support of the industry by the Russian media shows weak efficiency, since it does not always reflect the real state of affairs.

On the basis of the conducted analyses, it is possible to answer the research questions posed. (1) The available empirical data does not make it possible to clearly state the strength of the impact of the political crisis on the functioning of the tourism economy in Crimea. However, the observations carried out indicate a significant reduction in inbound tourism both from the territory of the Russian Federation and especially from Ukraine, along with the inhibition of inbound foreign tourism. (2) The media is used as an instrument of the policy pursued by the Russian public authorities to stimulate tourist inbound traffic to Crimea from the territory of the Russian Federation. The purpose of the information is an attempt to present Crimea as an area that allows you to take advantage of the tourist offer. (3) Table 4 presents the list of events from 2014-2019, which were presented in the media, along with an assessment of their impact on the functioning of the Crimea tourist 
destination. (4) Improving the crisis situation in the functioning of the Crimean tourism economy is not possible through the implementation of a media policy only, but through specific measures aimed at preserving the natural and cultural heritage, maintaining and developing tourism infrastructure, creating a tourism offer with attention to its quality and ensuring appropriate conditions for the safety of tourists' stay.

The problem raised in the study has not been the subject of scientific research so far. Along with the potentially changing political and socioeconomic situation, the issues raised in the study should be covered by in-depth research. The high level of tourist attractiveness of Crimea and, at the same time, the high share of the tourism economy in the macroeconomic effects determine the need to take measures in the field of tourism policy towards sustainable tourism development, in order to shape positive relations between the natural and cultural heritage of Crimea, society and the tourism economy in this area.

Activities aimed at the development of sustainable tourism should include accessibility of the tourist offer for domestic and foreign tourists, activities for the protection of natural and cultural heritage, maintenance and development of tourist infrastructure along with limiting the degradation of the already existing elements of the transport, accommodation and catering base, sports and recreational facilities and other elements of the accompanying and para-tourism base, influencing the safety of both entities of the tourism economy and, above all, tourists. The issue of security is particularly important as it results from the very unstable political and social situation in the neighboring regions of Ukraine, which are affected by the military crisis. Responsibility for the scope of activities related to the sustainable development of the Crimean tourism economy should be taken both by the central authorities of the Russian Federation in cooperation with public institutions at the regional and local level.

\subsection{Final Conclusions}

The main issue of the conducted research is the role of the media in supporting the functioning of the Crimea tourist destination. The most important problem resulting from the conducted observations is the limitation to activities related to the Russian market. Although it is a market that has a decisive influence on incoming traffic to Crimea during the research period, it should be born in mind that before the crisis, Crimea was an international destination. Therefore, when a satisfactory level of security is achieved, measures should be taken to create the image of Crimea as a tourist destination on foreign markets. To this end, the international media should be used to ensure a sufficient level of credibility and trust by the international public. Social media should also be an important support tool. The media message should provide real and credible information, while supporting the tourist destination, and thus access to its heritage, tourist infrastructure, and the tourist offer.

The studies performed concern the period preceding the COVID-19 pandemic. This is another crisis phenomenon with a global dimension, which additionally exacerbates the crisis of the Crimean tourism economy. As long as travel restrictions in internal and international relations persist, the possibilities of counteracting the crisis are very limited. The time of the pandemic, however, may become a certain period of preparation for public institutions in order to be able to ensure the possibility of returning tourists to the Crimea in the near future. This will be possible thanks to the creation of cooperation with entities of the tourism economy, including travel agencies and carriers, and with the support of national and international media.

\subsection{Inference Limitations}

The conducted research concerns information support of the media for a selected tourist destination operating in crisis conditions. The results of the research and the conclusions presented concern only the reality of one specific destination, subject to a political, social and military crisis, and from 2020, as well as other destinations, also 
epidemic. The presented analyses can be the basis for comparative research in other tourist areas affected by crises.

Author Contributions: Conceptualization, A.P. and H.Z.; methodology, A.P., H.Z.; validation, A.P., H.Z.; formal analysis, A.P., H.Z.; investigation, A.P., H.Z.; resources, A.P., H.Z.; data curation, H.Z.; Writing-Original draft preparation, A.P, H.Z.; Writing—Review and editing, A.P., H.Z.; visualization, H.Z.; supervision, A.P.; project administration, A.P.; funding acquisition, A.P. All authors have read and agreed to the published version of the manuscript.

Funding: This research received no external funding.

Institutional Review Board Statement: Not applicable.

Informed Consent Statement: Not applicable.

Data Availability Statement: The data presented in this study are openly available. Information on data sources is available in the cited list.

Conflicts of Interest: The authors declare no conflict of interest.

\section{References}

1. Chou, M.C. Does tourism development promote economic growth in transition countries? A panel data analysis. Econ. Model. 2013, 33, 226-232. [CrossRef]

2. Roaf, J.; Atoyan, R.; Joshi, B.; Krogulski, K. Regional Economic Issues-Special Report 25 Years of Transition: Post-Communist Europe and the IMF; International Monetary Fund: Washington, DC, USA, 2014; pp. 29-32. [CrossRef]

3. Klitsounova, V.; Slocum, S.L. Introduction. In Tourism Development in Post-Soviet Nations; Slocum, S., Klitsounova, V., Eds.; Palgrave Macmillan: Cham, Switzerland, 2020; pp. 1-11. [CrossRef]

4. Banaszkiewicz, M.; Graburn, N.; Owsianowska, S. Tourism in (Post)socialist Eastern Europe. J. Tour. Cult. Chang. 2017, 15, 109-121. [CrossRef]

5. Pforr, C.; Hosie, P.J. Crisis Management in Tourism. J. Travel Tour. Mark. 2008, 23, 249-264. [CrossRef]

6. Panasiuk, A. Rynek turystyczny Struktura Procesy Tendencje; Difin: Warszawa, Poland, 2019; 374p.

7. Henderson, J.C. Tourism Crises: Causes, Consequences and Management; Butterworth-Heinemann: Oxford, UK, $2007 ;$ p. 4.

8. Glaesser, D. Crisis Management in the Tourism Industry; Butterworth-Heinemann: Oxford, UK, 2006; p. 27.

9. The Week. Available online: https://theweek.com/captured/449985/crimea-picturesque-tourist-spot-wont-visiting-anytimesoon (accessed on 29 October 2020).

10. The National Geographic. Available online: https://www.nationalgeographic.com/travel/best-trips-2013/crimea-ukrainephotos / (accessed on 29 October 2020).

11. Срибный, В.И. Обеспечение Экономической Безопасности Республики Крым: Угрозы и Контрмеры. J. Int. Econ. Aff. 2019, 9, 1697-1710. [CrossRef]

12. Panasiuk, A. The Contemporary Model of Tourism Policy. Ekon. Probl. Tur. 2017, 39, 31-41. [CrossRef]

13. Polyakova, E.O.; Bochkareva, T.V. The study of the Crimea as a platform of interests of national and international mass media. Mod. Sci. 2018, 6, 36-39.

14. Pratt, S.; Tolkach, D. The politics of tourism statistics. Int. J. Tour. Res. 2018, 20, 299-307. [CrossRef]

15. Кошелева, А.Н.; Мирзоев, И.ф.-О. Механизмы интенсификации развития туризма в Республике Крым в переходный период. Региональная Экономика и Управление 2016, 1, 18. Available online: https:/ / eee-region.ru/article/4502/ (accessed on 29 October 2020).

16. Surdej, A. Determinanty Regulacji Administracyjnoprawnych w Oddziaływaniu Państwa na Gospodarkę; Wydawnictwo Akademii Ekonomicznej w Krakowie: Kraków, Poland, 2006; pp. 49-50.

17. Boyer, R. La Théorie de la Regulation une Analyze Critique; La Découverte: Paris, France, 1986; 142p.

18. Scott, N. Tourism and Policy; Goodfellow Publishers Ltd.: Oxford, UK, 2011; pp. 1-64.

19. Panasiuk, A.; Wszendybył-Skulska, E. Social Aspects of Tourism Policy in the European Union. The Example of Poland and Slovakia. Economies 2021, 9, 16. [CrossRef]

20. Bramwell, B.; Lane, B. Sustainable tourism and the evolving roles of government planning. J. Sustain. Tour. 2010, 18, 1-5. [CrossRef]

21. Paunović, I.; Jovanović, V. Sustainable mountain tourism in word and deed: A comparative analysis in the macro regions of the Alps and the Dinarides. Acta Geogr. Slov. 2019, 59. [CrossRef]

22. Adamczyk, J.; Nitkiewicz, T. Programowanie Zrównoważonego Rozwoju Przedsiębiorstw; PWE: Warszawa, Poland, 2008.

23. Zaręba, D. Ekoturystyka; Wydawnictwo Naukowe PWN: Warszawa, Poland, 2010; 201p.

24. Pender, L.; Sharpley, R. Zarzadzanie Turystyka; PWE: Warszawa, Poland, 2008.

25. Nijkamp, P.; Verdonkschot, S. Suistainable tourism development: A case study of Lesobos. In Suistainable Tourism Development Coccossis H. Aldershot, Burlington-Singapore-Sydney; Nijkkamp, P., Ed.; Ashgate Publishing: Amsterdam, The Netherlands, 2000. 
26. Ritchie, J.B.; Crouch, G.I. The Competitive Destination: A Sustainable Tourism Perspective; CABI Publishing: London, UK, 2003.

27. Tang, Z. An integrated approach to evaluating the coupling coordination between tourism and the environment. Tour. Manag. 2015, 46, 11-19. [CrossRef]

28. Panasiuk, A. Contemporary Threats to the Development of Sustainable Urban Tourism. In Handbook of Sustainable Development and Leisure Services; Lubowiecki-Vikuk, A., de Sousa, B.M.B., Dercan, B., Leal Filho, W., Eds.; Springer: Berlin/Heidelberg, Germany, 2021; pp. 141-156.

29. Panasiuk, A. (Ed.) Ekonomika Turystyki i Rekreacji; WN PWN: Warszawa, Poland, 2011.

30. Kurek, W. (Ed.) Turystyka; WN PWN: Warszawa, Poland, 2008.

31. Panasiuk, A. Crises in Functioning of Urban Tourism Destinations. Studia Perieget. 2019, 3, 13-25.

32. PWN. Available online: https://encyklopedia.pwn.pl/haslo/informacja;3914686.html (accessed on 6 February 2021).

33. Knight, H. Risk, Uncertainty and Profit; Publ. Houghton Mifflin: Boston, MA, USA, 1921; 381p.

34. Panasiuk, A. Personnel as a Factor of Production in Development of Reginal Tourism Economy-A Coceptual Paper. J. Entrep. Manag. Innov. 2013, 9, 57-67.

35. Stiglitz, J. The contributions of the economics of information to twentieth century economics. Q. J. Econ. 2000, 115, 1449. [CrossRef]

36. Babik, W. Słownik Encyklopedyczny Informacji, Języków i Systemów Informacyjno-Wyszukiwawczych; Stowarzyszenie Bibliotekarzy Polskich: Warszawa, Poland, 2002; p. 307.

37. Stabryła, A. Podstawy Organizacji i Zarządzania Podejścia i Koncepcje Badawcze; Wydawnictwo Uniwersytetu Ekonomicznego w Krakowie: Kraków, Poland, 2012; p. 359.

38. Пивнев, Е.С. Теория Управления; Изд-во ТМЦДО: Томск, Russia, 2005; p. 130.

39. Czekaj, J. Podstawy Zarządzania Informacja; Wydawnictwo Uniwersytetu Ekonomicznego w Krakowie: Kraków, Poland, 2012; p. 36.

40. Batorski, J. Instrumenty Zarzadzania Kryzysowego w Przedsiębiorstwie Turystycznym. Perspektywa Organizacyjnego Uczenia Sie; Wydawnictwo Uniwersytetu Jagiellońskiego: Kraków, Poland, 2013; p. 14.

41. Regester, M. Zarzadzanie Kryzysem; PWE: Warszawa, Poland, 2005; p. 115.

42. Coombs, W.T. Ongoing Crisis Communication: Planning, Managing, and Responding; Sage Publications: New York, NY, USA, 2014; p. 2.

43. Fearn-Banks, K. Crisis Communications: A Casebook Approach; Routledge: New York, NY, USA, 2016; p. 4.

44. Hall, J.R. In the Jaws of a Crisis. Dir. Boards 1991, 15, 17-20.

45. Seymour, M. Crafting a Crisis Communications Plan. Dir. Boards 1991, 15, 26-29.

46. Hallahan, K. Seven Models of Framing: Implications for Public Relations. J. Public Relat. Res. 1999, 11, 205-242. [CrossRef]

47. Bergstrand, F.; Landgren, J. Information systems in crisis. Crisis Inf. Manag. 2012, 121-137. [CrossRef]

48. Smith, J.L. When It Hits the Fan: A Public Relations Practioner's Guide to Crisis Communications; Georgia State University: Atlanta, GA, USA, 2007. Available online: https:/ / scholarworks.gsu.edu/cgi/viewcontent.cgi?article=1018\&context=communication_theses (accessed on 29 October 2020).

49. Ulmer, R.; Sellnow, T.L.; Seeger, M.W. Effective Crisis Communication: Moving from Crisis to Opportunity; SAGE Publications: Thousand Oaks, CA, USA, 2007; p. 1.

50. Hallahan, K.; Holtzhausen, D.; van Ruler, B.; Verčič, D.; Sriramesh, K. Defining Strategic Communication. Int. J. Strateg. Commun. 2007, 1, 3-35. [CrossRef]

51. Гаврилов, А.А. Средства воздействияСМИ на общественное сознание в условиях информационного общества. Молодой Ученый 2012, 8, 152-155.

52. Кра-Мурза, С.Г. МанипулированиеСознанием; Издательство: Moscow, Russia, 2005.

53. Panasiuk, A. Marka turystyczna jako instrument zarządzania regionalna gospodarka turystyczną w warunkach sytuacji kryzysowych. Wspótczesne Zarządzanie 2013, 1, 21-30. [CrossRef]

54. Ivanov, S.; Idzhylova, K.; Webster, C. Impacts of the entry of the Autonomous Republic of Crimea into the Russian Federation on its tourism industry: An exploratory study. Tour. Manag. 2016, 54, 162-169. [CrossRef]

55. Ministry of Resorts and Tourism of the Republic of Crimea. Available online: https://mtur.rk.gov.ru/ru/structure/43 (accessed on 29 October 2020).

56. Ministry of Resorts and Tourism of the Republic of Crimea. Available online: https://mtur.rk.gov.ru/ru/structure/45 (accessed on 29 October 2020).

57. Ministry of Resorts and Tourism of the Republic of Crimea. Available online: https://mtur.rk.gov.ru/ru/document/show/30 (accessed on 29 October 2020).

58. Ministry of Resorts and Tourism of the Republic of Crimea. Available online: https://mtur.rk.gov.ru/uploads/mtur/attachments / /d4/1d/8c/d98f00b204e9800998ecf8427e/phpMDdz5m_2017.pdf (accessed on 29 October 2020).

59. Ministry of Resorts and Tourism of the Republic of Crimea. Available online: https://mtur.rk.gov.ru/uploads/mtur/attachments/ /d4/1d/8c/d98f00b204e9800998ecf8427e/php1ePuTP_12.pdf (accessed on 29 October 2020).

60. Ministry of Resorts and Tourism of the Republic of Crimea. Available online: https://mtur.rk.gov.ru/ru/structure/1294 (accessed on 29 October 2020). 
61. Балдина, О.И. Статистический Ежегодник. Республика Крым. 2017; Изд-Bo: Simferopol, Russia, 2018; pp. 111-113. Available online: https:/ / crimea.gks.ru/storage/mediabank/\%D0\%95\%D0\%B6\%D0\%B5\%D0\%B3\%D0\%BE\%D0\%B4\%D0\%BD\%D0\%B8 $\%$ D0 \%BA $\% 20 \%$ D1\%81\%D0\%B0\%D0\%B9\%D1\%82.pdf (accessed on 29 October 2020).

62. The European External Action Service's East StratCom Task Force. Available online: https://is.gd/xXdRfb (accessed on 29 October 2020).

63. The Russian Public Opinion Research Center. Available online: https://www.wciom.com/index.php?id=139 (accessed on 29 October 2020).

64. The Medialogia. Available online: https://www.mlg.ru/about/technologies/ (accessed on 29 October 2020).

65. Кравченко, Н.А.; Иванов, С.И. Причины и условия роста уровня теневой экономики(на примере Крымского федерального округа). Общество иПраво 2015, 4, 165-168.

66. Vyazovik, S.M. Current state and development of the tourist industry as a budget-funding project in Autonomous Republic of Crimea. Vestn. Astrakhan State Tech. Univ. Ser. Econ. 2017, 89-94. [CrossRef]

67. Нехайчук, Д.В.; Чигидин, О.Д. Теневая Экономика: Анализ Развития. В Эффективность Бизнеса в Условиях Международной Нестабильности; Трофимова, В.В., Еd.; АНО“Крымский Институт Бизнеса”: Simferopol, Russia, 2017; pp. 6-15. Available online: https:/ / www.elibrary.ru/item.asp?id=32392055\& (accessed on 29 October 2020).

68. The eSubscription to United Nations Documents. Resolution 68/262 dated 27 March 2014. Available online: https:/ undocs.org/ en/A/RES/68/262 (accessed on 29 October 2020).

69. Kostyaev, S.; Yushkov, I. Features of Crimea Integration and Adaptation to Russian Socio-Political System. Humanities. Bull. Univ. Financ. 2015, 5, 45-52. [CrossRef]

70. Kayukova, E.P.; Yurovsky, Y.G. Water Resources of the Crimea. Water Resour. 2017, 44, 886-891. [CrossRef]

71. Pavlishyna, N. Development of the Crimea business in the conditions of geopolitical uncertainty. Conf. Proc. 2019, 462-469. [CrossRef]

72. Укрзалізниця. Available online: https://is.gd/jHUksg (accessed on 29 October 2020).

73. Швец, А.Б. Влияние геополитического фактора на туристско-рекреационную деятельность в Крыму. Вернадского ГеографияГеология 2017, 3, 133-140.

74. Craig, W.; Ivanov, S.H.; Gavrilina, V.; Idzhylova, K.; Sypchenko, L. Hotel Industry's Reactions to the Crimea Crisis. E-Rev. Tour. Res. 2017, 14, 57-71. Available online: https://journals.tdl.org/ertr/index.php/ertr/article/view/103/19 (accessed on 6 March 2021).

75. Донцова, О.И.; Засько, В.Н. Перспективы Республики Крым как туристического кластера Российскойфедерации. РоссийскоеПредпринимательство 2016, 17, 823-832. [CrossRef]

76. Официальный интернет-портал правовой информации. Постановление Кабинета министров Республики Крымот22.14.2016 г. № 104 „О внесении изменений в государственную программу развития курортов и туризма в Республике Крым на 2005-2017 годы". Available online: http://publication.pravo.gov.ru/Document/View/9100201603280002 (accessed on 29 October 2020).

77. Минэкономразвития Р федеральной целевой программыСоциально-экономическое развитие Республики Крым и г. Севастополя до 2022 года”. Available online: https:/ /is.gd/7Ij0ki (accessed on 29 October 2020).

78. Ministry of Resorts and Tourism of the Republic of Crimea. Available online: https://mtur.rk.gov.ru/ru/structure/245 (accessed on 29 October 2020).

79. Гусакова, Е. Почему Крым неосвоил федеральные деньги на развитие туризма. РоссийскаяГазета 2019, 290. Available online: https: / /is.gd/1hXzAT (accessed on 29 October 2020).

80. Минэкономразвития Р $\phi$. федеральная целевая программа “Социально-экономическое развитие Республики Крым и г. Севастополя до 2022 года". Available online: https: / faip.economy.gov.ru/cgi/uis/faip.cgi/G1/ol/2020?reg=95 (accessed on 29 October 2020).

81. Гук, О. А; Буркальцева, Д.Д. Развитие туристической индустрии Республики Крым. Сервис в России и за рубежом 2019, 13, 119-129. [CrossRef]

82. Левчук, К.С.; Аблаев, Р.Р.; Оценка реализации мероприятий по обеспечению энергетической безопасности Республики Крым и г. Севастополя. Вестник молодежной науки2019. Available online: http:/ /vestnikmolnauki.ru/wp-content/uploads / 2019/07/Ablaev-320.pdf (accessed on 29 October 2020).

83. Oborin, M.; Rodenko, I. Energy security of the Republic of Crimea under the international sanctions. Serv. Russ. Abroad 2018, 119-130. [CrossRef]

84. Дробязко, Н.Е.; Гришина, Е.А. Проблемы водоснабжения рекреационных районов Крыма. Вестник ИМСИТ 2019, 3 , 50-52. Available online: https://www.imsit.ru/images/html/elibraries/vestnik/2019_3.pdf (accessed on 29 October 2020).

85. Vasilenko, V.A. Hydro-economic problems of Crimea and their solutions. Reg. Res. Russ. 2017, 7, 89-96. [CrossRef]

86. Likhacheva, A. Global Water Challenge and Prospects for Russian Agenda. Russ. Chang. World 2020, 161-178. [CrossRef]

87. Dunaeva, I.; Popovych, V.; Melnichuk, A.; Terleev, V.; Nikonorov, A.; Mirschel, W.; Topaj, A.; Shishov, D. Water deficits in the water economics complex of Crimea. Meteorol. Hydrol. Water Manag. 2019, 7, 57-67. [CrossRef] 
88. Иванютин, Н.М. Возможность использования слабоминерализованных поверхностных и подземных вод для целей хозяйственно-питьевого водоснабжения иорошения в Крыму. ПутиПовышения Эффективности Орошаемого Земледелия 2017, 2, 106-111.

89. Kirienkova, I.O.; Nichkova, L.A.; Lvov, A.V. Investigation of quality of underground water of the Crimean peninsula. Monit. Syst. Environ. 2019, 3, 132-137. [CrossRef]

90. Шохина, Е. Как Крымобеспечат водой. Ведомости2020. Available online: https:/ /www.vedomosti.ru/economics/articles/20 20/10/20/843978-krim-obespechat (accessed on 29 October 2020).

91. Coombs, W.T. The Protective Powers of Crisis Response Strategies. J. Promot. Manag. 2006, 12, 241-260. [CrossRef]

92. Cavlek, N. Tour operators and destination safety. Ann. Tour. Res. 2002, 29, 478-496. [CrossRef]

93. Kim, D.; Perdue, R.R. The Influence of Image on Destination Attractiveness. J. Travel Tour. Mark. 2011, 28, 225-239. [CrossRef]

94. Детектор Медіа. Уральские“утки” взлетают в Крыму ... . Available online: https://detector.media/community/article/33 96/2004-08-13-uralskie-utki-vzletayut-v-krymu/ (accessed on 29 October 2020).

95. Манойло, А.В. Государственная ИнформационнаяПолитика В Особых Условиях; Издательство МИфИ: Москва, Russia, 2003.

96. Баранов, Н.А. ИнформационнаяПолитика РоссииВ УсловияхГеополитического Противоборства; ИТ“AРИАЛ”: Simferopol, Russia, 2017.

97. Изиляева, Л.О. Основные тенденции современной российской государственной информационной политики. Экономика и Управление 2017, 1, 8-13.

98. Fattibene, D. Information Warfare: A New Pillar of Russia's Foreign Policy. Int. Spect. 2016, 51, 134-136. [CrossRef]

99. The Russian Public Opinion Research Center. Люди в цифре: Эпоха постправды. Available online: https://wciom.ru/ fileadmin/file/reports_conferences/2019/2019-12-13_mediaforum.pdf (accessed on 29 October 2020).

100. The Russian Public Opinion Research Center. Летний сезон-2015: Крым. Available online: https://infographics.wciom.ru/ theme-archive/politics/russia-regions/regions-economic/article/letnii-sezon-2015-krym.html (accessed on 29 October 2020).

101. The Russian Public Opinion Research Center. Итоги Туристического Лета 2019. Available online: https:/ / wciom.ru/fileadmin/ file/reports_conferences/2019/2019-09-24_Summer_rest.pdf (accessed on 29 October 2020).

102. Алиев, А.И. Проблемы и перспективы развития туризма в Республике Крым. Молодая Наука 2019, 103, $105-106$.

103. Абрамова, Л.С.; Троценко, О.И.; Проблемы и перспективы развития туризма в Крыму иСевастополе. Вектор Экономики2020. Available online: http://www.vectoreconomy.ru/images/publications/2020/3/economicsmanagement/ Abramova_Trotsenko.pdf (accessed on 29 October 2020).

104. Ivanov, S.; Sypchenko, L.; Webster, C. International Sanctions and Russia's Hotel Industry: The Impact on Business and Coping Mechanisms of Hoteliers. Tour. Plan. Dev. 2016, 14, 430-441. [CrossRef] 